\title{
A FURTHER CASE OF ANTI-LUTHERAN IMMUNIZATION, WITH SOME STUDIES ON ITS CAPACITY FOR HUMAN SENSITIZATION
}

\author{
BY \\ U. R. MAINWARING \\ National Blood Transfusion Service, Regional Serological Laboratory (Oxford Region) \\ AND \\ M. M. PICKLES \\ Department of Pathology, Radcliffe Infirmary, Oxford
}

(RECEIVED FOR PUBLICATION, JUNE 22, 1948)

The "Lutheran" antibody was first described by Callender, Race, and Paykoç (1945) in the serum of a patient who developed a number of antibodies in response to multiple transfusions of blood. Callender and Race (1946) showed that the red cells of 8 to 9 per cent of the English population were agglutinated by this antibody, that it was inherited as a Mendelian dominant, and that it was unrelated to the $\mathrm{ABO}, \mathrm{MN}, \mathrm{P}$, or $\mathrm{Rh}$ blood groups.

This paper reports a second example of this antibody found during the investigation of a transfusion reaction, and some attempt is made to assess the immunizing capacity of the Lutheran antigen.

\section{Case History}

In February, 1946, a man (A. T.) aged 38 with cirrhosis of the liver was admitted to the Radcliffe Infirmary (Reg. No. 10771/46) for treatment of bleeding oesophageal varices. He had suffered from recurrent haematemeses since 1931, and had been transfused, latter:y at about yearly intervals. In the two months before his admission to this hospital he had received four transfusions, most of which had been accompanied by rigors. On March 1, 1946, he was transfused with four pints of group $\mathrm{O} R$ h-positive blood. A slight reaction was noted though not reported till later. On March 7 he received a further two pints of $O \mathrm{Rh}$ positive blood; this transfusion was followed by marked jaundice and haemoglobinuria, and on investigation two days later his blood group was found to be $O \mathrm{Rh}$-negative, with no evidence of surviving Rh-positive cells, thus showing that he had destroyed all the blood transfused. His serum contained an incomplete anti-D antibody (titre 1:128 in concentrated albumin and 1:512 Coombs' titration), the obvious cause of his transfusion reaction. In addition there was an agglutinating antibody active at $20^{\circ}$ and $37^{\circ} \mathrm{C}$. This was also present at the same titre of $1: 16$ in the pre-transfusion sample taken on
March 1, 1946, which suggests that it had not caused the transfusion reaction. In fact all the bottles given had been cross-matched and found to be compatible and were later shown to be Lutheran-negative. As the serum also agglutinated the cells of a known Lutheran-positive donor, it was investigated in parallel with the original anti-Lutheran serum by Dr. S. T. Callender and Dr. R. R. Race. It agglutio nated all of twelve Lutheran-positive and failed tog agglutinate all of forty-seven Lutheran-negative bloods. The probability of such a coincidence be윽 ing due to chance is infinitely small.

During April and May, 1946, the patient was injected with small amounts of Lutheran-positive cells. His subsequent transfusions were compatible both for the $R h$ and Lutheran factors. His antibody titres in June, 1946, were 1:512 incomplete anti-D (in albumin) and 1:16 anti-Lutheran. A year later the titre of the incomp'ete anti-D antibody had dropped to $1: 64$ and the anti-Lutheran antibody reacted weakly at a titre of $1: 1$. In January, 1948, no anti-Lutheran antibody was detectable in his serum.

The type of agglutination was similar to that previously described-compact agglutinates among many unagglutinated cells-and though with many of the test cells the serum gave slightly stronger reactions at $37^{\circ} \mathrm{C}$, other cells were agglutinated more strongly at $20^{\circ} \mathrm{C}$.

\section{Serological Investigations}

Three hundred and sixteen random bloods were tested with the serum; twenty-six were positive (8.23 per cent). It was possible to distinguish strong and weakly reacting types of positive cells ; of the twenty-six Lutheran-positive cells fifteen were strong reactors or $L_{1}$ and eleven weak or $L_{2}$. When the serum (titre $1: 16$ ) was absorbed with an equal volume of packed cells the $L_{1}$ cells removed all the agglutinin, whereas when it was absorbed with the $\mathbf{L}_{2}$ cells, which removed all antibody capable of reacting with themselves, it 
TABLE

\begin{tabular}{|c|c|c|c|c|c|c|c|c|c|}
\hline \multirow{3}{*}{$\begin{array}{c}\begin{array}{c}\text { Name and } \\
\text { Reg. No. }\end{array} \\
\begin{array}{c}\text { E.W. } \\
21754 / 44\end{array}\end{array}$} & \multicolumn{3}{|c|}{ Recipients } & \multirow{2}{*}{\multicolumn{2}{|c|}{$\begin{array}{c}\text { Donors' } \\
\text { Rh and } \\
\text { Lutheran Group }\end{array}$}} & \multirow{3}{*}{$\begin{array}{c}\begin{array}{c}\text { Serum } \\
\text { tested } \\
\text { (days) }\end{array} \\
\\
15 \\
25 \\
31\end{array}$} & \multirow{2}{*}{\multicolumn{3}{|c|}{ Immune investigations }} \\
\hline & \multirow{2}{*}{$\frac{\text { Age }}{46}$} & \multirow{2}{*}{$\frac{\text { Diagnosis }}{\text { Duodenal ulcer }}$} & \multirow{2}{*}{ 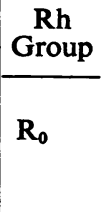 } & & & & & & \\
\hline & & & & $\begin{array}{l}R_{1} R_{2} \\
R_{1} \mathbf{r}\end{array}$ & $\begin{array}{l}\mathbf{L}+ \\
\mathbf{L}+\end{array}$ & & $\begin{array}{ll}1: 16 & \text { Anti-L } \\
1: 4 & \Rightarrow \\
: 2 \quad "\end{array}$ & $\begin{array}{l}\text { theran } \\
\text { " }\end{array}$ & $\begin{array}{l}\text { All previous } \\
\text { donors L - }\end{array}$ \\
\hline$\underset{36929 / 44}{\text { A.P. }}$ & 46 & Cholecystectomy & $\mathbf{R}_{\mathbf{2}}$ & $\begin{array}{l}\mathbf{R}_{\mathbf{1}} \mathbf{R}_{\mathbf{2}} \\
\mathbf{R}_{\mathbf{1}} \mathbf{R}_{\mathbf{2}}\end{array}$ & $\begin{array}{l}\mathrm{L}+ \\
\mathrm{L}+\end{array}$ & $\begin{array}{l}28 \\
36 \\
72\end{array}$ & $\begin{array}{l}1: 4 \\
1: 2 \\
\text { Negative }\end{array}$ & ", & $\begin{array}{l}\text { Previous donors } \\
\text { not available }\end{array}$ \\
\hline$\underset{45572 / 45}{\text { A.C. }}$ & 56 & Anastomotic ulcer & $\mathbf{R}_{\mathbf{1}}$ & $\begin{array}{l}R_{1} r \\
R_{0} r\end{array}$ & $\begin{array}{l}\mathbf{L}+ \\
\mathbf{L}+\end{array}$ & $\begin{array}{l}11 \\
17\end{array}$ & $\begin{array}{l}\text { Negative } \\
\text { Negative }\end{array}$ & $\mathbf{F}$ & $\begin{array}{l}\text { Previous donors } \\
\text { not available }\end{array}$ \\
\hline $\begin{array}{l}\text { C.B. } \\
\text { 57191/46 }\end{array}$ & 12 & $\begin{array}{l}\text { Traumatic splenec- } \\
\text { tomy }\end{array}$ & N.T. & $\mathbf{R}_{\mathbf{1}}$ & $\mathbf{L}+$ & 13 & Negative & & \\
\hline$\underset{54323 / 46}{\text { A.T. }}$ & 67 & Partial gastrectomy & $\mathbf{R}_{1} \mathbf{r}$ & $\begin{array}{l}R_{1} r \\
R^{\prime \prime} r \\
R_{1} R_{1}\end{array}$ & $\begin{array}{l}\mathbf{L}+ \\
\mathbf{L}+ \\
\mathbf{L}+\end{array}$ & $\begin{array}{l}30 \\
68\end{array}$ & $\begin{array}{l}\text { Negative } \\
\text { Negative }\end{array}$ & & \\
\hline $\begin{array}{l}\text { W.M.M. } \\
\text { 50740/46 }\end{array}$ & 59 & Prostatectomy & $\mathbf{R}_{\mathbf{2}}$ & $\mathbf{r r}$ & $\mathbf{L}+$ & 20 & Negative & & \\
\hline$\underset{\text { 55258/46 }}{\text { P.M. }}$ & 32 & $\begin{array}{l}\text { Hysterectomy and } \\
\text { salpingo-oophor- } \\
\text { ectomy }\end{array}$ & $\mathbf{r r}$ & $\begin{array}{l}\mathbf{R}_{\mathbf{1}} \mathbf{r} \\
\mathbf{R}_{\mathbf{1}} \mathbf{R}_{\mathbf{1}}\end{array}$ & $\begin{array}{l}\mathbf{L}+ \\
\mathbf{L}+\end{array}$ & $\begin{array}{l}24 \\
58 \\
98\end{array}$ & $\begin{array}{l}\text { Negative } \\
\text { Negative } \\
\text { Negative }\end{array}$ & & \\
\hline $\begin{array}{l}\text { H.P. } \\
\text { P.P. }\end{array}$ & & Prostatectomy & N.T. & $\begin{array}{l}\mathbf{R}_{1} \mathbf{r} \\
\text { N.T. }\end{array}$ & $\begin{array}{l}\mathbf{L}+ \\
\mathbf{L}-\end{array}$ & $\begin{array}{l}10 \\
42\end{array}$ & $\begin{array}{l}\text { Negative } \\
\text { Negative }\end{array}$ & & \\
\hline
\end{tabular}

N.T. $=$ Not tested.

still agglutinated the more strongly positive bloods. This is analogous to the subdivision of the blood group $A$ into $A_{1}$ and $A_{2}$ with the $\alpha_{1}$ serum.

\begin{tabular}{lccc}
\multicolumn{9}{c}{ Cells } \\
Serum before absorption & $\mathrm{L}_{1}$ & $\mathrm{~L}_{2}$ & L negative \\
Serum-absorbed $\mathrm{L}_{1}$ cells & - & + & - \\
Serum-absorbed $\mathrm{L}_{2}$ cells & + & - & - \\
S & -
\end{tabular}

This result cannot be explained by the dosage effect of homozygous and heterozygous bloods, as the expected frequency of Lutheran-positive homozygotes in 316 bloods would be less than one, whereas fifteen were observed. Five families have been studied, two of the $L_{1}$ and three of the $L_{2}$ type. In all cases the antigen was present in the same form in all members of the family. The evidence is in favour of there being three allelomorphs of the gene, their approximate gene frequencies calculated from the 316 bloods being $L_{1} 2.5$ per cent, $L_{2} 1.8$ per cent, and 1 (Lutherannegative) 95.7 per cent.

The occurrence of the same type of immune antibody in a second patient in the same hospital within two years suggests that the Lutheran factor is moderately antigenic in man, though this could not be accurately assessed, as both patients had developed other immune antibodies. The first case reported (Callender and others, 1945) was known to be hypersensitive to all blood antigens. It was therefore decided to transfuse Lutheran-. negative patients with Lutheran-positive blood to determine the importance of the antigen in transfusion practice. Eight suitable patients were selected from those requiring transfusions, and their sera were examined for atypical antibodies. Each received without any reaction one or two pints of Lutheran-positive blood. Their sera were 
re-examined at approximately fortnightly intervals for two months. Two out of the eight patients developed "Lutheran" antibodies of the agglutinating type, but no other antibodies, either agglutinating or incomplete, were detected in any of the eight patients, either on testing against a random panel of test cells or against the blood donors, who were recalled and whose cells were tested against the sera from the patients to whom their blood had been given. Both the patients who developed anti-Lutheran antibodies and one of those who did not respond had received earlier transfusions. In one of these (E. W.) all four donors of the earlier transfusions were tested and found to be Lutheran-negative; in the other two cases the donors were not traced. In both these deliberately immunized patients the anti-Lutheran antibody was detectable in the serum for a short time only. In the case of A. P. it was present at a titre of $1: 4$ twenty-eight days after transfusion, and it fell rapidly and was no longer evident fortyfour days later. In E. W. the maximum titre of 1 : 16 was found fifteen days after transfusion; it fell to $1: 2$ during the succeeding fortnight.

\section{Discussion}

The chance finding of a further anti-Lutheran antibody and the immunization of two out of eight patients by transfusion with Lutheran-positive blood suggests that the Lutheran antigen is moderately antigenic in man and that supplies of suitable test serum could be obtained fairly readily. However, its antigenic capacity cannot be compared with most of the other blood factors antigenic in man, since very few systematic studies have been made. It had generally been considered that only 2 to 4 per cent of $R$ h-negative people were sensitized by transfusion of $\mathrm{Rh}$ positive blood, but Hattersley (1947) has shown that eleven (55 per cent) of twenty Rh-negative Servicemen who had been previously transfused developed anti-Rh agglutinins. Diamond (1948) has confirmed this high incidence of immunization of Rh-negative subjects transfused with blood from unselected donors. In his series of over 500 cases, 46 per cent contained anti-Rh agglutinins. Other specific antibodies developing in response to transfusion have occasionally been reported. It is probable that they occur more readily than is generally recognized, as they are usually detected only in the investigations of a transfusion reaction or in the cross-matching of blood for a further transfusion.
Because of the rarity of the Lutheran antigen, its role as a potential cause of transfusion reactions is remote when unselected blood is used. In contrast to the anti-Rh agglutinin the serum titre of the anti-Lutheran antibody does not seem to be well maintained. In the case reported by Callender and Race (1946) the antibody was demonstrated in the serum for only about seven weeks, and though it was present in our first case for sixteen months after the first observation the titre had fallen from $1: 16$ to $1: 4$ in five weeks, subsequent reimmunization probably contributing to its persistence. In the experimentally immunized patients the titre was falling rapidly during the second month after transfusion. There was no indication of clinical incompatibility of transfusion in either of these recipients, though the donor cells must have been rapidly eliminated in case $E$. W., where an antibody titre of $1: 16$ was found fourteen days after transfusion; and though some changes in the peripheral haemoglobin levels were observed during this time these were not significant, as the patient was losing blood from a bleeding peptic ulcer.

Although the Lutheran antigen has not yet been proved to be the cause of a clinical transfusion incompatibility, it should, in view of its potential immunizing capacity, be considered when a transfusion reaction is being investigated.

\section{Summary}

A second example of human immunization to the Lutheran factor is described. In eight Lutheran-negative patients purposely transfused with Lutheran-positive blood, two developed antiLutheran antibodies. In none of the cases as yet described was there evidence of clinical incompatibility.

It has been found that there are strongly and weakly reacting Lutheran-positive cells, $L_{1}$ and $L_{2}$, analogous to the $A_{1}$ and $A_{2}$ groups. The importance of the Lutheran factor as a blood antigen is discussed.

We thank Dr. R. R. Race and Dr. S. T. Callender for their confirmation of the specificity of the first serum encountered, and Dr. J. Grant for her coordination of the selected transfusions.

REFERENCES

Callender, S. T., Race, R. R., and Paykoc, Z. V. (1945). Brit. med. J., 2,83 .

Callender, S. T., and Race, R. R. (1946). Ann. Eugen. Camb., 13, 102. Hattersley, P. G. (1947). P. Lab. clin. Med., 32, 423. 